\title{
Ağır iş yükü, iş-aile çatışması ve yönetici desteği arasındaki ilişkiler: Otomotiv sektörü üzerine bir araştırma
}

\section{The relationships between work overload, work- family conflict and supervisory support: A Research on automotive industry}

\section{Sabiha Sevinç Altaş}

Dr. Öğr. Üyesi, Sakarya Üniversitesi, Sağlık Hizmetleri MYO, Tıbbi Hizmetler ve Teknikleri Bölümü, Türkiye, e-mail: sabihas@sakarya.edu.tr

\section{Öz}

Bu araştırma ile 137 otomotiv sektörü çalışanı için ağır iş yükü, iş-aile çatışması ve yönetici desteği ilişkileri araştırılmaktadır. Kocaeli ilinde faaliyet gösteren bir otomotiv fabrikasının137 çalışanından elde edilen veriler kullanılarak değişkenler arasındaki ilişki incelenmiştir. Veriler doğrulayıcı faktör analizi, korelasyon analizi ve regresyon modelleri ile analiz edilmiştir. Yapılan korelasyon analizi ile ağır-iş yükü, iş-aile çatışması ve yönetici desteği değişkenleri arasında anlamlı ilişkiler tespit edilmiştir. Regresyon analizi ile ağır iş yükünün yönetici desteğini istatistiksel olarak negatif etkilediği bulgulanmıştır. Ağır iş yükünün, iş-aile çatışmasını istatistiksel olarak pozitif etkilediği bulgulanmıştır. Yönetici desteği, iş-aile çatışması değişkenini istatistiksel olarak negatif etkilediği tespit edilmiştir. Bu çalışma otomotiv sektörü çalışanlarının duygu durumlarına önem verilerek çalışan memnuniyetini arttırmayı amaçlayan örgüt yöneticileri için önemli bulgular sağlamaktadır.

Anahtar kelimeler: Ağır İş Yükü, İş-Aile Çatışması, Yönetici Desteği

JEL kodları: M10, M12, C12

Abstract

In this research, the relationships between work overload, work-family conflict and supervisory support on 137 automotive industry workers. Relations between parameters were analyzed usingthe data that obtained from 137 automotive industry workers in a factory operating in Kocaeli province. The data were analyzed by verificative factor analysis, correlation analysis and regression models. Significant relations between correlation analysis work 
overload, work-family conflict and supervisory support were discovered. Consequence of the regression analysis, it was found that work overload affect supervisory support statistically negative. It has been found that work overload has a statistically positive effect on work-family conflict. It was determined that supervisory support had a statistically negative effect on the work-family conflict variable. This research provides important findings for managers aiming to increase employee satisfaction by paying attention to automotive industry workers naturally felt emotions.

Keywords: Work Overload, Work-Family Conflict, Supervisory Support

JEL codes: M10, M12,C12

\section{GİRIŞ}

İş hayatının çalışanlar ve aileleri için önemi büyüktür. İşgörenlerin iş ortamında maruz kaldıkları olumlu ya da olumsuz durumlar onları çok etkilemektedir. İş ortamında özellikle ağır iş yükü önemli bir problem olarak karşımıza çıkmaktadır. Uzun süre bu şekilde çalışan bireyler yıpranmaktadır ve sonrasında birey ve örgüt açısından olumsuz sonuçlar doğmaktadır. Son dönemlerde örgütlerin en önemli rekabet avantajı olan işgörenlerinden beklentilerini arttırdığı farkedilmektedir. Bu beklentileri karşılayabilmek için mücadele eden çalışanlar artan rolleri karşısında zorlanmaktadır. İş dışındaki rollerini gerçekleştirirken eksik olmak kendilerinde baskı yaratabilmektedir.

İş hayatının bir diğer sorunu da iş-aile çatışmasıdır. İş-aile çatışması bireyin iş ortamında, ev ortaminda veya sosyal ortamlarındaki rollerinin çatışmasından doğmaktadır. Roller arasındaki önceliğin belirlenememesi, denge kurulamaması çalışanı iş-aile çatışmasına götürmektedir. İş-aile çatışması kişinin rolleri arasında denge kuramamasından kaynaklanmaktadır. İş ve aile sistemleri farklı gibi görünse de birbirine bağlıdır (Clark, 2000:748).

Araştırmaya konu olan değişkenlerden biri yönetici desteği; bir çalışanın yöneticisinden işle ve de duygusal olarak hissettiği, algıladı $\breve{1} 1$ destektir ((Ng ve Sorensen,2008). Yönetici desteği, iş-aile yaşamının dengelenmesine yardım etmektedir. $\mathrm{Bu}$ yönde verilen destek, bir projenin teslim süresini uzatmayı içerdiği gibi, çalışan ve yönetici arasında ortak duyguları da içermektedir (Turgut,2011: 162).
Bu çalışmanın ilk bölümünde ağır-iş yükü, iş-aile çatışması ve yönetici desteği kavramları açıklanmıştır. Otomotiv sektörü çalışanları üzerinde gerçekleştirilen anket çalışması ve verilerin SPSS 25 programı ile değerlendirilmesiyle erişilen bulgular değerlendirilmiştir.

\section{LITERATÜR TARAMASI}

\section{1. İş-Aile Çatışması}

İş ile aile, erişkin hayatının iki merkezi sistemini oluşturur ve insan davranışı üzerinde çok etkilidir (Huang vd.,2004:80). Her ne kadar geçmişte iş ile aile hayatı ayrı kavramlar gibi görülse de günümüzde bu kavramların birbirini etkilediği kabul edilmektedir. İş ve aile kavramları arasında dinamik bir ilişki bulunmaktadır. Ayrıca karşl1ıklı bir etkileşim söz konusudur.

Dubrin'e göre (1997) iş-aile çatışması, bireylerin farklı rollerinden kaynaklanmaktadır. Bireylerin anne-baba olarak ve de eş olarak rolleri bulunmaktadır. Zaman zaman bu rollerin çatışması iş-aile çatışmasını da beraberinde getirmektedir (Turunç,Çelik,2010:212). Parasuraman, Simmers (2001:555-556)'a göre iş-aile çatışması özellikle iş-aile rollerinde aynı anda meydana gelen roller sonucunda çakışma ve uyumsuzluk durumudur. İş-aile çatışması, iş ve ailedeki rollerin diğer sorumluluklardan ve rollerden dolayı daha da güçleştiği roller arası çatışma durumudur ( Vaydonaff, 1998: 749 ).

Greenhaus, Beutel (1985: 77-83)'e göre iş-aile çatışması üç şekilde yaşanmaktadır. Zaman temelli, duygu temelli ya da davranış temelli olarak ifade etmektedir. Zaman temelli şeklinde ortaya çıan iş-aile çatışması, rollerden birine ilişkin za- 
man baskısının diğer rolü etkilemesi ile ilgilidir. Bir role yerine getirmek fazla zaman harcamayı gerektirdiğinde diğer rolün hakkının yeterince verilemediğinde oluşan çatışmadır. Duygu temelli iş-aile çatışması, iş hayatında bir rolü yerine getirmekten kaynaklanan bitkinlik ve gerginliğin diğer rolü gerçekleştirmede sıkıntı yaratmasıdır. Yani kişi işi ya da ailesinden kaynaklı olarak bitkinlik, gerginlik, tahammülsüzlük, alınganlık, duyarsızlık, endişe gibi olumsuz durumlar yaşadığında kişinin diğer rolünde gösterdiği performans negatif olarak etkilenmektedir (Bacharach vd., 1991: 42). Davranış temelli iş-aile çatışması, bir rolle ilgili davranışlarla diğer rolle ilgili davranışların arasındaki uyumsuzluk ile oluşmaktadır.

Kadın çalışanların diğerlerine göre daha fazla çatışma yaşaması muhtemel görülmektedir (Özkan vd., 2015:84). Farklı bir ifadeyle iş-yaşam dengesini kurmada sorun yaşanmaktadır (Topgül,2016:218). İş-aile yaşamı dengesini tanımlamaya ilişkin Clark(2000) tarafından "İş-Aile Sınır Teorisi" geliştirilmiştir. Çalışanların iş yaşamı ve aile yaşamından oluşan iki dünyasını açıklamaktadır. İş yaşamında çalışanlar "sınır geçiciler" olarak ifade edilmektedir. Kişiler rutin olarak sınırları geçmektedir. Kişiler çevrelerini şekillendirmekte ve şekillenmektedir. İş-Aile S1nır Teorisi ile iş-aile dünyaları arasındaki geçişlerde denge oluşturulması açıklanmaktadır. Bu denge çok önemlidir. Sınırları geçen kişiler her geçişte kendilerini şekillendirmek ve aynı zamanda uyumlaştırmak zorunda kalmaktadır.

Greenhaus vd., (2003:513) iş-aile dengesini üç öğe ile tanımlamaktadırlar:

- Zaman dengesi: İş ile aile hayatının gerektirdiği rollere eşit miktarda zaman ayrılması

- Katılım dengesi: İş ile aile hayatının gerektirdiği rollere eşit miktarda katılım ve psikolojik olarak emek harcama

- Memnuniyet dengesi: İş ile aile hayatının gerektirdiği rollerden eşit miktarda memnuniyet duyma.

\subsection{Ağır İș Yükü}

İş yükü kavramı, kişinin iş hayatında kendisine yüklenen işin normal standartların üzerinde olduğuna yönelik oluşan algisıdır (Keser, 2006:105)

Birey ve iş arasındaki iş yükü açısından uyumun olmaması, çoğunlukla tükenmişliğin altında yatan bitkinliğe yol açmaktadır (Leiter ve Maslach 2005). Akşam saatlerinde mesaiye kalma ve haftasonu çalışma gerektiren görevler, zaman baskısı, teslim tarihleri, bilginin fazla olması, gözetimde olan kişi sayısının fazlalığı iş yükünü belirleyen çeşitli kriterlerdir (Wallace, 1999: 801).

Torun,Ercan(2006) tarafından gerçekleştirilen niteliksel bir çalışmada iş yükü sorgulanmıştır. İşten aileye yönelik olarak yaşanan zaman temelli bir çatışmanın en önemli belirleyicisinin iş yükü olduğunu ifade etmişlerdir (Turgut, 2011:160).

Maslach ve Leiner (1997)'e göre yoğun iş yükü ile işgörenlerin üzerinde dikkat eksikliği, görevleri tam olarak tamamlayamama, stres, yorgunluk gibi özelliklerin tespit edilmesine ve bu durumunda iş gören performansının düşmesine neden olduğu belirtilmiştir (Şirin,Yücel,2020:244).

Hart ve Staveland (1988) iş yükünü, işin gereklilikleri ve getirdiği stres ile işi bitirebilmek için gerekli tüm çabaların oluşturduğunu ifade etmektedir. Kişinin iş yükü algısını, işten beklentileri, işe duyduğu önyargı ve geçmiş deneyimleri etkilemektedir. İşyükü algılamasında tüm bunların yanısıra deneyimlenmiş iş, zaman sorunları, performans beklentisi, işin gerektirdiği fiziksel ve zihinsel talepler de rol oynamaktadır. Herkesin sahip olduğu farklı tecrübe, işyükü algılamasının da farklılaşmasını sağlamaktadır (Şirin,Yücel, 2020:244).

Eroğlu(2000)'na göre aşırı iş yükü, iki gruba ayrılarak açıklanabilir. Birincisi niceliksel ya da kantitatif iş yükü; diğeri ise niteliksel ya da kalitatif iş yüküdür. Niceliksel iş yükü, çalışanın yapması gereken bir iş için "zamanın yetersizliği", belirli bir zamanda yapılacak "çok farklı işlerin olması" ile "yapılacak işlerin fiziki olarak ağır ve yorucu olması" olarak ifade edilebilir. Buna göre, bazı görevlerin önceden belirlenen bir tarihte veya zaman diliminde yapılmasını gerektiren çalışma düzeni, kişide gerilim ve stres 
oluşturan yoğun, aşırı yüklenme durumudur. Niteliksel iş yükü ise yerine getirilmesi gereken işin nitelikleri ve yapacak kişinin nitelikleriyle ilgilidir. Bu nitelikler arasında işi yapacak kişinin aleyhinde bir fark varsa niteliksel iş yükünden bahsedilmektedir. Çünkü bu durumda, işi yapacak işgören işin gerektirdiği bilgi, kabiliyet ve kişisel bir takım özelliklere sahip olmad1ğında, bu iş işgörene zor gelecektir (Cam,2011:3)

\subsection{Yönetici Desteği}

Yönetici desteği, çalışanların ilk amirleri tarafından gördükleri desteği ifade etmektedir (Yoon,Lim, 1999:925). Yönetici desteği algısı, işgörenlerin yöneticilerinin onları ne kadar önemsediği ve işe yaptıkları katkılara değer verme düzeylerine yönelik inançlarını ifade etmektedir (Pohl, Galletta, 2016: 62). Burki vd.(1992)'ne göre, yönetici desteği işgörenlere destek olunması, teşvik edilmesi ve ilgi gösterilmesidir (Babin ve Boles, 1996: 60).

Bhanthumnavin (2000:157-160) yönetici desteğini işgörenlerin motivasyonunu arttırmak için bilgisel, maddi ve duygusal destek biçimi olarak tanımlamaktadır. Bilgisel yönetici desteğinde işle ilgili içeriğe odaklanılmaktadır. Ödül, geri bildirim, ceza, rehberlik etme, değerlendirme, işgörenlerin iş etkinliğini artırmak için bilgi ve becerilerden oluşmaktadır. Yöneticilerin çalışanlarına sunduğu bilgisel desteğin, iş bilgi ve önerileri dişında da faydası bulunmaktadır. Çalışanda kendi yönetici ile birlikte, kurumu tarafından da değerli olduğu algısı oluşacaktır. İşgören kurumunda kendisini önemli hissedecektir. Maddesel yönetici desteği, maddi destek, yardım, zaman, maddi kaynaklar, ihtiyaç duyulan hizmetlerin sağlanması olarak tanımlanabilir. Yani çalışma gruplarında ihtiyaç duyulan maddesel destektir. Maddi destek Kraimer, Wayne(2004) tarafından finansal destek şeklinde ifade edilmektedir. Bir kurumdaki çalışanların finansal ihtiyaçlarının giderilmesidir. Aynı zamanda çalışanların performansına göre verilecek maddi desteğin bir ödül sistemi olarak düşünülebileceğini söylemiştir. Duygusal yönetici desteği, aynı zamanda çalışma gruplarında iş motivasyonu ve iş kalitesinin arttırılması için de önemlidir. Yöneticinin çalışanlarına ilgi, sevgi ve saygı gösterme, astlara değer verme, onları kabul etme, taktir etme, yardım etme, zorluklar karşısında başedebilmek için destek verme şeklinde açılanmaktadır. Hem sözlü hem de sözsüz şekilde gerçekleşebilir. Sarılmak ya da el sıkışmak sözsüz şeklin örneğidir.

\subsection{Değișkenlere İlișkin Literatür Taraması}

İlgili yazında ağır iş yükü, iş-aile çatışması ve yönetici desteği arasındaki ilişkiler incelendiğinde, ağır iş yükü ve yönetici desteğinin arasındaki negatif ilişki göze çarpmaktadır. Ağır iş yükü ve iş-aile çatışması arasındaki pozitif ilişkiler görülmektedir. Yönetici desteği ile iş-aile çatışması arasında negatif ilişki bulunmaktadır. Aşağıda ilgili yazındaki çalışmaların bir bölümüne yer verilmektedir.

Carlson ve Perrewe (1999), 403 kamu çalışanları üzerinde gerçekleştirdikleri çalışmalarında, yönetici ile örgütsel destek arttıkça ağır iş yükü ve iş stresi algısının azaldığını bulmuşlardır. Böylece iş-aile çatışması oluşma ihtimalini de azaltacağ ${ }_{1}$ sonucu elde edilmiştir. Yoon, Thye (2000), Kore'de üç üniversite hastanesi çalışanlarına yaptıkları çalışmada, ağır iş yükü ile yönetici desteği arasında anlamlı ve negatif bir ilişki olduğu görülmüştür. Glaser ve arkadaşları (1999), yönetici desteğinin azalıp iş yükü arttığında stresinde arttı̆̆ını bulgulamıştır.

Turgut'un (2011), hizmet sektörü çalışanları üzerinde gerçekleştirdiği çalışmasında, ağır iş yükünün iş tutkusunu azalarak iş-aile çatışmasını arttırdığ 1 görülmektedir. Yıldırım ve Aycan (2008) hemşireler üzerinde gerçekleştirdikleri çalışmada, ağır iş yükü ile iş aile çatışması ilişkisinde pozitif yönlü ve anlamlı bir ilişki olduğunu bulgulamıştır. Ahuja, vd.,(2007) çalışmalarını bilgisayar mühendisleri üzerinde gerçekleştirmiştir. Bireye iş yükü ağır geldikçe, iş-aile çatışmasının da fazlalaştığı göze çarpmaktadır.

Frye \& Breaugh (2004:202) yönetici desteği ve aile-iş çatışmasını nasıl etkilediği hakkında çok az şey bilindiğini ifade etmektedir. Karatepe, Kılıç(2007) ilgili değişkenler arasındaki ilişkiyi Kıbrıs'ta otel çalışanları üzerinde sorgulamışlardır. Otel çalışanlarında yönetici desteğinin iş-aile çatışması üzerinde negatif etkisi bulunmaktadır. Yönetici desteği verildikçe iş-aile ve aile-iş azalmaktadır. O'Driscoll vd., (2003) Yeni 
Zelanda'da yöneticiler üzerinde yaptıkları çalışmada, yönetici ve meslektaş desteği fazla olduğunda iş-aile çatışmasının düşük olduğu tespit edilmiştir. Thompson, Prottas (2006), destek algısının meslektaş ve yönetici açısından yüksek olmasının, iş-aile çatışmasını düşürücü etkisi olduğu sonucuna ulaşmışlardır. Breaugh ve Frye (2008)'e göre, bir çalışan destekçi bir iş imkanına sahip olduğunda, esnek çalışma saatleri artmakta, algıladıkları iş-aile çatışması azalmaktadır.

\section{ARAŞTIRMANIN YÖNTEMI}

\subsection{Araştırmanın Amacı ve Yöntemi}

Araştırmanın temel amacı otomotiv sektörü çalışanlarının iş hayatlarında mücadele ettikleri ağır iş yükünün etkisiyle yaşadıkları iş aile çatışması ve yönetici desteğinin bu faktörler üzerindeki etkisinin saptanmasıdır. Ağır iş yükü, işgörenin örgütünde kendisinden istenen iş yükünün beklediğinden ya da olması gerekenden fazla olduğu yönündeki algısıdır. Ağır iş yükünün olumsuz sonuçlarından biri de iş-aile çatışmasıdır. Birbirinden farklı gibi görünmesine rağmen birbirine bağlı bu iki kavramın arasındaki uyumsuzluk kişinin veriminin düşmesine sebep olmaktadır. İşgörenin işine karşı soğumasına sebep olurken kendisini de yıpratmaktadır. Fakat bu iki kavramı olumlu anlamda etkileyeceği düşünülen yönetici desteği, işgörenlerin ihtiyaç duyduğu anlarda yöneticilerinin her anlamda yanında olmasıdır. Yöneticisinden madden, bilgisel ve duygusal olarak destek aldığını hisseden işgören olumlu tutum ve davranışlar gösterecektir.

\subsection{Araştırmanın Evreni ve Örneklem Tespiti}

Araştırma Kocaeli ilinde faaliyet gösteren bir otomobil fabrikasında kolayda örnekleme yöntemi ile gerçekleştirilmiştir. Şubat-Mart tarihleri arasında (16.02.2021-E.11495 etik kurul izni ile) anketler internet ortamında gerçekleştirilmiştir. Covid-19 Pandemi sürecinin çalışma koşullarını sebebiyle 137 işgörenden geri dönüş olmuştur.

\subsection{Araştırmanın Modeli ve Hipotezleri}

İlgili yazın incelendiğinde geçmişten günümüze ağır iş yükü, iş aile çatışması ve yönetici desteği ile ilgili çalışmalar görülmektedir. Ağır iş yükü ve yönetici desteği arasında ilişkinin araştırıldı- ğ1 çalışmalar da negatif yönlü ve anlamlı ilişki tespit edilmiştir (Kırmeyer ve Dougherty, 1988; Carlson ve Perrewe, 1999; Glaser, vd., 1999; Yoon ve Thye, 2000; Fu ve Shaffer, 2001). İlgili yazın doğrultusunda ve elde edilen sonuçlara dayanarak H1 hipotezi ortaya konmuştur;

H1: 'Ağır iş yükü ile yönetici desteği arasında anlamlı ve negatif yönlü bir ilişki vardır.'

Ağır iş yükü ve iş-aile çatışması ile ilgili yazın taramasında ilgili değişkenler arasındaki ilişkide pozitif yönlü, anlamlı bir ilişki olduğu bulunmuştur (Goh, vd., 2015; Lu, vd.,2008; Voydanoff, 1988; Ahuja, vd., 2007; Carlson ve Kacmar, 2000; Yıldırım D., Aycan Z., 2008; Turgut, 2011; Goh, vd., 2015; Ilies, vd., 2007). İlgili yazın doğrultusunda ve elde edilen sonuçlara dayanarak H2 hipotezi ortaya konmuştur;

H2: 'Ağır iş yükü ile iş-aile çatışması arasında anlamlı ve pozitif yönlü bir ilişki vardır.'

Yönetici desteği ve iş-aile çatışması ile ilgili yazın taramasında ilgili değişkenler arasındaki ilişkide negatif yönlü ve anlamlı bir ilişki olduğu tespit edilmiştir (Major, vd., 2008; O'Driscoll vd., 2003; Breaugh ve Frye, 2008; Thompson ve Prottas, 2006; Mesmer-Magus, vd., 2008; Ng ve Sorensen, 2008; Wang, vd., 2010; Casper, vd., 2011; Shirom, vd., 2011). İlgili yazın doğrultusunda ve elde edilen sonuçlara dayanarak H3 hipotezi ortaya konmuştur;

H3: 'Yönetici desteği ile iş-aile çatışması arasında anlamlı ve negatif bir ilişki vardır.'

Bulguların tespit edilip, sunulması amaciyla kurulan model Şekil 1'de görülmektedir: 


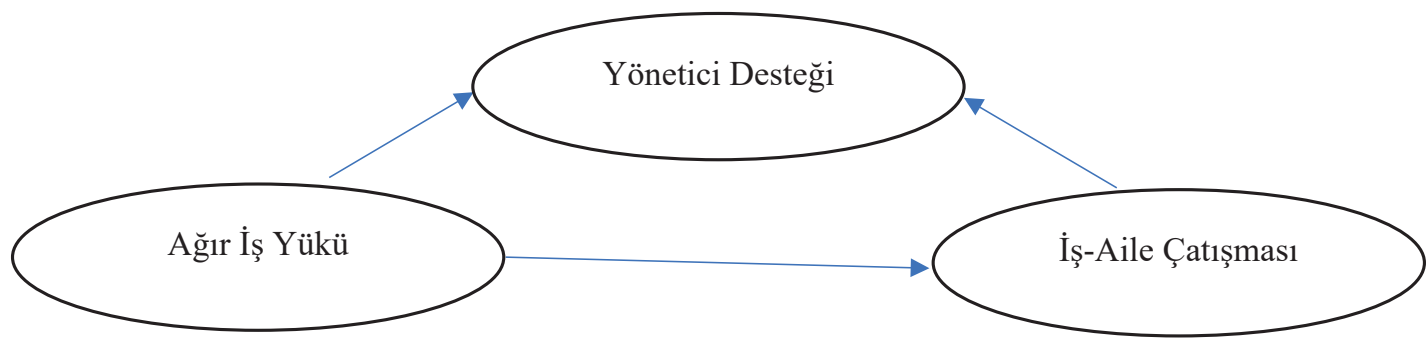

Şekil 1. Araştırma Modeli

\subsection{Araştırmada Kullanılan Ölçekler}

Araştırmada otomotiv sektörü çalışanlarının algıladıkları ağır iş yükünü ölçmek için Imoisili (1985)'nin oluşturduğu ölçekten faydalanılmıştır. Tek boyuta ve 5 maddeye sahiptir. Araştırmanın bir diğer değişkeni çalışanların yaşadıkları iş-aile çatışmasıdır. Bu değişkeni ölçmek için Netemeyer vd. (1996)'nin ölçeği kullanılmıştır. Yine tek boyutlu ve 5 maddeye sahiptir. Çalışanların iş ortamında yöneticilerinden gördükleri desteği ölçmek için Anderson vd.(2002) tarafından geliştirilen ve 6 sorudan oluşan tek boyutlu ölçek kullanılmıştır. Tüm bu ölçeklerle hazırlanan anketlerde 5'li Likert ölçeğinden yararlanıl- mıştır.

\subsection{Analiz Yöntemleri}

Araştırmadan elde edilen verilerin analizinde ölçeklerin geçerlilik ve güvenilirliğini ölçmek için Cronbach's Alpha güvenilirlik analizi ve doğrulayıcı faktör analizi kullanılmıştır. Daha sonra ağır iş yükü, iş-aile çatışması ve yönetici desteği değişkenlerine yönelik tanımlayıcı istatistiklere yer verilmiştir. Değişkenler arası ilişkiler için korelasyon analizi ve regresyon analizi kullanılmıştır. SPSS 25 istatistik programından faydalanılmıştır.

Tablo 1. Demografik Özellikler

\begin{tabular}{|c|c|c|c|}
\hline Cinsiyet & $\begin{array}{l}\text { Kadın } \\
\text { Erkek }\end{array}$ & $\begin{array}{l}\mathrm{N} \\
97 \\
40\end{array}$ & $\begin{array}{c}\% \% \\
70,8 \\
29,2\end{array}$ \\
\hline Yaş & $\begin{array}{l}18-23 \\
24-29 \\
30-35 \\
36-41 \\
42-47 \\
48-53 \\
54 \text { ve üstü }\end{array}$ & $\begin{array}{c}7 \\
31 \\
24 \\
29 \\
33 \\
11 \\
2\end{array}$ & $\begin{array}{c}5,4 \\
22,6 \\
17,5 \\
21,2 \\
24,1 \\
8 \\
1,2\end{array}$ \\
\hline Medeni Durum & $\begin{array}{l}\text { Evli } \\
\text { Bekar }\end{array}$ & $\begin{array}{c}110 \\
27\end{array}$ & $\begin{array}{l}80,3 \\
19,7\end{array}$ \\
\hline Eğitim Durumu & $\begin{array}{l}\text { İlkokul-ortaokul Lise } \\
\text { Ön Lisans } \\
\text { Lisans } \\
\text { Lisansüstü-doktora }\end{array}$ & $\begin{array}{c}14 \\
84 \\
20 \\
15 \\
4\end{array}$ & $\begin{array}{c}10,2 \\
61,3 \\
14,6 \\
10,9 \\
3\end{array}$ \\
\hline Aylık Gelir & $\begin{array}{l}3000 \text { ve alt1 } \\
3001-4000 \\
4001-5000 \\
5001-6000 \\
6001 \text { ve üstü }\end{array}$ & $\begin{array}{l}18 \\
33 \\
52 \\
19 \\
15\end{array}$ & $\begin{array}{c}13,1 \\
24,1 \\
38 \\
13,9 \\
10,9\end{array}$ \\
\hline Kıdem & $\begin{array}{l}1-5 \text { y1l } \\
6-10 \text { y1l } \\
11-15 \text { y1l } \\
16-20 \text { y1l } \\
21 \text { y1l ve üstü }\end{array}$ & $\begin{array}{l}43 \\
35 \\
25 \\
24 \\
10\end{array}$ & $\begin{array}{l}31,4 \\
25,5 \\
18,2 \\
17,5 \\
7,3 \\
\end{array}$ \\
\hline
\end{tabular}




\subsection{Analiz ve Bulgular}

Araştırma Kocaeli ilinde faaliyet gösteren bir otomobil fabrikasında gerçekleştirilmiştir. Katılımcıların demografik özellikleri incelendiğinde cevaplayanların \%70,8'i erkek, \%29,2'si kadındır. $\% 80,3^{\prime}$ ü evli ve \%19,7'si bekardır. \%24,1'i 42-47 yaş aralığında ve \%22,9'u 24-29 yaş aralığındadır. $\% 61,3$ 'ü lise, $\% 14,6$ 'sı ön lisans mezuniyetine sahiptir. \%31,4'ü 1-5 yıldır, \%25,5'i 6-10 yıldır bu işletme içinde çalışmaktadır. \%38'i 4001-5000 TL gelir düzeyine sahiptir.

\subsubsection{Kullanılan Ölçeğin Doğrulayıcı Faktör Analizi}

Değişkenlere yönelik faktör yapısını belirlemek amaciyla varimaks dönüşümlü keşifsel faktör analizinden yararlanılmıştır. Yönetici desteği, ağır iş yükü ve iş aile değişkenleri tek boyuttan oluşmaktadır. Faktörlere yönelik güvenilirlik katsayılarının yüksek seviyede olduğu Tablo 2'de ifade edilmektedir. Faktör yük değerlerinin 0.50'nin oldukça üzerinde olduğu görülmektedir. Tamamının tek faktör altında toplandığı tespit edilen değişkenlerden yönetici desteğinin örneklem yeterlilik katsayısı Kaiser-Meyer Olkin (KMO) ,913 olarak tespit edilmiştir. Bu değer ölçeğin içsel tutarlılığa sahip olduğunu göstermektedir. Ağır iş yükü ölçeğinin örneklem yeterlilik katsayısı (KMO) ,818 olarak bulunmuştur. İş-Aile çatışması ölçeğinin örneklem yeterlilik katsayısı (KMO), 802 olarak bulunmuştur. KMO değerleri faktör analizinin kullanılabilirliğini göstermektedir. Bu oranın 0,60'dan yüksek olması uygun görülmektedir (Büyüköztürk, 2002, 10-28). Bu araştırmada üç değişkene ait KMO değerlerinin de $0,60^{\prime}$ ın oldukça üzerinde olduğu görülmektedir.

\subsubsection{Güvenilirlik Değerleri, Korelasyonlar ve Regresyon Analizi Sonuçları}

Araştırma modelinin değişkenleri arasındaki ilişkileri incelemek amacıyla korelasyon ve regresyon analizi yapılmıştır. Analiz bulguları Tablo 3'de görülmektedir. Otomotiv sektörü çalışanlarında "yönetici desteği" ve "ağır iş yükü" değişkenleri arasında negatif yönlü anlamlı ilişki bulunmuştur. Yine "yönetici desteği" ve "iş-aile çatışması" değişkeni arasında negatif yönlü anlamlı bir ilişki bulunmuştur. Fakat "ağır iş yükü" değişkeni ile "iş aile çatışması" değişkenleri arasında pozitif yönlü ve kuvvetli ilişki bulgulanmiştır.

Tablo 2. Değişkenlerin Faktör Yükleri

\begin{tabular}{|c|c|c|c|}
\hline SORU & FAKTÖR1 & FAKTÖR2 & FAKTÖR3 \\
\hline YD1 &, 899 & & \\
\hline YD2 & 907 & & \\
\hline YD3 & 901 & & \\
\hline YD4 & 925 & & \\
\hline YD5 & , 896 & & \\
\hline YD6 & , 856 & & \\
\hline AGIR1 & & ,889 & \\
\hline AGIR2 & & , 891 & \\
\hline AGIR3 & & 906 & \\
\hline AGIR4 & & ,853 & \\
\hline AGIR5 & & ,720 & \\
\hline AILE1 & & & ,650 \\
\hline AILE2 & & & ,797 \\
\hline AILE3 & & & ,875 \\
\hline AILE4 & & & 715 \\
\hline AILE5 & & & ,833 \\
\hline $\begin{array}{l}\text { YD: Yönet } \\
\text { Çatışması }\end{array}$ & eği, AG & ir İşs Yükü, & IILE: İş-Aile \\
\hline
\end{tabular}


Yapılan regresyon analizi sonuçlarına göre (Tablo4), ağır iş yükünün yönetici desteğini istatistiksel olarak negatif olarak etkilediği görülmekte$\operatorname{dir}(\beta=-, 285, \mathrm{p}<.01)$.

Yapılan regresyon analizi sonuçlarına göre (Tablo5), ağır iş yükünün iş-aile çatışmasını istatistiksel olarak pozitif olarak etkilediği görülmektedir $(\beta=, 567, \mathrm{p}<.01)$.

Yapılan regresyon analizi sonuçlarına göre (Tab- lo6), yönetici desteğinin iş-aile çatışmasını istatistiksel olarak negatif olarak etkilediği görülmektedir $(\beta=-, 337, \mathrm{p}<.01)$.

\section{SONUÇ VE ÖNERİLER}

Ağır iş yükü, iş-aile çatışması ve yönetici desteği değişkenleri arasındaki ilişkilerin incelenmesine yönelik gerçekleştirilen bu araştırma Kocaeli ilinde faaliyet gösteren bir otomobil fabrikasında çalışan 137 işgörenden elde edilen verilerle ger-

Tablo 3. Ortalama, SSapma Ve Korelasyon Değerleri

\begin{tabular}{|l|l|l|l|l|l|}
\hline & Ortl. & SSapma & 1 & 2 & 3 \\
\hline $\begin{array}{l}\text { 1.Yönetici } \\
\text { Desteği }\end{array}$ & 3,2287 &, 9659 & 0,951 & & \\
\hline $\begin{array}{l}\text { 2.Ağır İş } \\
\text { Yükü }\end{array}$ & 2,5956 & 1,0697 &,$- 316^{* *}$ & 0,906 & \\
\hline $\begin{array}{l}\text { 3.İş Aile } \\
\text { Çatışmasi }\end{array}$ & 3,0613 &, 8995 &,$- 362^{* *}$ &, $675^{* *}$ & 0,829 \\
\hline
\end{tabular}

Tablo 4. Ağır İş Yükünün Yönetici Desteği Üzerindeki Etkileri

\begin{tabular}{|l|c|c|}
\hline Bağımsız Değişken & \multicolumn{2}{|c|}{$\begin{array}{c}\text { Yönetici Desteği } \\
\text { Model1 }\end{array}$} \\
\hline A ğır İş Yükü & B & T \\
&,- 285 & $-3,866^{* *}$ \\
Model F & 14,942 & \\
Model R2 & 0,093 & \\
$* * \mathrm{p}<.01$ & & \\
$* \mathrm{p}<.05$ (tek taraflı) & & \\
\hline
\end{tabular}

Tablo 5. Ağır İş Yükünün İş-Aile Çatışması Üzerindeki Etkileri

\begin{tabular}{|l|l|l|}
\hline Bağımsız Değişken & \multicolumn{2}{|c|}{$\begin{array}{c}\text { İs-Aile Çatışmas1 } \\
\text { Model2 }\end{array}$} \\
\hline A ğır İş Yükü & B & T \\
Model F &, 567 & $10,616^{* *}$ \\
$\begin{array}{l}\text { Model R2 } \\
* * p<.01\end{array}$ & 112,705 & \\
$* \mathrm{p}<.05$ (tek tarafl1) &, 455 & \\
\hline
\end{tabular}

Tablo 6. Yönetici Desteğinin İş-Aile Çatışması Üzerindeki Etkileri

\begin{tabular}{|l|l|l|}
\hline Bağımsız Değişken & \multicolumn{2}{|c|}{$\begin{array}{c}\text { İs-Aile Çatışmas1 } \\
\text { Model3 }\end{array}$} \\
\hline Yönetici Desteği & B & T \\
&,- 337 & $-4,513 * *$ \\
Model F & 20,371 & \\
Model R2 &, 131 & \\
$* * p<.01$ & & \\
$* \mathrm{p}<.05$ (tek tarafl1) & & \\
\hline
\end{tabular}


çekleştirilmiştir. Çalışmanın ilk kısmında ağır-iş yükü, iş-aile çatışması ve yönetici desteği kavramları açıklanmıştır. Akabinde bu değişkenler arasındaki ilişkilerin araştırıldığ 1 çalışmalara yer verilmiştir. Anket yöntemiyle elde edilen veriler analiz edilerek yorumlanmıştır.

İnsan hayatında iş yaşamının önemi büyüktür. Kişiler günlük yaşamlarının önemli bir kısmını işte geçirmektedir. Hatta işten ayrılıp eve döndüklerinde işle ilgili konular zihinlerini meşgul etmektedir. Bu durum günlük hayatın planlanmasına ve alınacak kararlara etki etmektedir.

Analiz sonuçlarına göre, cevaplayanların \%70,8'i erkek, \%80,3'ü evlidir. \%24,1'i 42-47 yaş aralığında ve $\% 22,9^{\prime}$ u $24-29$ yaş aralığındadır. $\% 61,3$ 'ü lise mezuniyetine sahiptir. \%31,4'ü 1-5 yıldır, \%25,5'i 6-10 yıldır bu işletme içinde çalışmaktadır. \%38'i 4001-5000 TL gelir düzeyine sahiptir. Yapılan regresyon analizi sonuçlarına göre, ağır iş yükünün yönetici desteğini istatistiksel olarak negatif olarak etkilediği görülmektedir $(\beta=-, 285, p<.01)$. A ğır iş yükünün iş-aile çatışmasını istatistiksel olarak pozitif olarak etkilediğ $i$ görülmektedir $(\beta=, 567, \mathrm{p}<.01)$. Yönetici desteğinin iş-aile çatışmasını istatistiksel olarak negatif olarak etkilediği görülmektedir $(\beta=-, 337, \mathrm{p}<.01)$. Elde edilen bulgular, literatürle paralellik göstermektedir.

Araştırma sonuçlarına göre, çalışanların yöneticilerinden gördükleri desteğin varlığı ya da eksikliği önemli sonuçlar doğurmaktadır. Bu doğrultuda, yöneticiler çalışanlardaki ağır iş-yükü algısını kırmak için personel sayılarını arttıracak yöntemler bulmalıdır. Samimi bir iş ortamı yaratarak, adaleti ve güveni oluşturmalıdır. Çalışanlara değer gördüklerini, önemsendiklerini hissettirmelidir. Yöneticilerin verdikleri destek ile ağır iş yükü algısı kırılacak ve iş-aile çatışması da azalacaktır.

Otomotiv sektöründe gerçekleştirilen bu çalışma sonuçları Kocaeli ilindeki 137 çalışanın görüşleri ile sınırlıdır. Sonuçlar farklı meslekler için genellenemez. İleride yapılacak çalışmalar için farklı sektör ve meslek grupları için örneklemler oluşturularak araştırmalar yapılması önerilmektedir.

\section{KAYNAKÇA}

AHUJA, M. K., CHUDOBA, K. M., KACMAR, C. J., MCKNIGHT, D. H., \& GEORGE, J. F. (2007). It road warriors: Balancing work-family conflict, job autonomy, and work overload to mitigate turnover intentions. Mis Quarterly, 31(1),1-17.

ANDERSON, S. E., COFFEY, B. S., \&AMP; BYERLY, R. T. (2002). Formal organizational initiatives and informal workplace practices: Links to work-family conflict and job-related outcomes.Journal of management, 28(6), 787-810.

BABIN, B. J. VE BOLES, J.S. (1996). The effects of perceived co-worker involvement and supervisor support on service provider role stress, perfrmance and job satisfaction. Journal of Retailing, 72(1), 57-75.

BACHARACH, S.B., BAMBERGER, P., CONLEY S.(1991). Work Home Conflict Among Nurses and Engineers: Mediating the Impact of Role Stress on Burnout and Satisfaction at Work, Journal of Organizational Behavior, 12 (1), 39-53.

BHANTHUMNAVIN, D. (2000), "Importance of supervisory social support and its implications for HRD in Thailand", Psychology and Developing Societies, 12, 155- 166.

BREAUGH, J. A., \& FRYE, N. K. (2008). Work-family conflict: The importance of familyfriendly employment practices and family-supportive supervisors. Journal of business and psychology, 22(4), 345-353.

BÜYÜKÖZTÜRK, Ş.(2002).Veri Analizi El Kitabı. Ankara: Pegem A. Yayıncilık.

CAM, E. (2011). Çalışma yaşamında stres ve kamu kesiminde kadın çalışanlar. Journal of Human Sciences, $8(1)$.

CARLSON, D. S., \& PERREWÉ, P. L. (1999). The role of social support in the stressor-strain relationship: An examination of work-family conflict. Journal of management, 25(4), 513-540.

CARLSON, D. S., \& KACMAR, M. K. (2000). Work-family conflict in the organization: Do life role values make a difference? Journal of Management, 26, 10311054

CASPER, W. J., HARRIS, C., TAYLOR-BIANCO, A., \& WAYNE, J. H. (2011). Work-family conflict, perceived supervisor support and organizational commitment among Brazilian professionals. Journal of Vocational Behavior, 79(3), 640-652.

CLARK, S. C. (2000). Work/family border theory: A 
new theory of work/family balance. Human Relations, 53(6), 747-770.

ÇELİK, M. \& TURUNÇ, Ö. ( 2010), Alg1lanan Örgütsel Desteğin Çalışanların İş-Aile, Aile-İş Çatışması, Örgütsel Özdeşleşme ve İşten Ayrılma Niyetine Etkisi: Savunma Sektöründe Bir Araştırma, Atatürk Üniversitesi Sosyal Bilimler Enstitüsü Dergisi 14 (1): 209-232

FRYE, N. K., \& BREAUGH, J. A. (2004). Family-friendly policies, supervisor support, work-family conflict, family-work conflict, and satisfaction: A test of a conceptual model. Journal of Business and Psychology, 19(2), 197-220.

FU, C. K., \& SHAFFER, M. A. (2001). The tug of work and family: Direct and indirect domainspecific determinants of work-family conflict. Personnel Review, 30(5), 502-52.

GLASER, D. N., TATUM, B. C., NEBEKER, D. M., SORENSON, R. C., \& AIELLO, J. R. (1999). Workload and social support: Effects on performance and stress. $\mathrm{Hu}$ man Performance, 12(2), 155-176.

GOH, Z., ILIES, R., \& WILSON, K. S. (2015). Supportive supervisors improve employees' daily lives: The role supervisors play in the impact of daily workload on life satisfaction via work-family conflict. Journal of Vocational Behavior, 89, 65-73.

GREENHAUS, J. H. \& BEUTELL, N. J. (1985). “Sources of Conflict Between Work and Family Roles", Academy of Management Review, 10(1),76-88.

GREENHAUS, J. H., COLLINS, K. M. \& SHAW, J. D. (2003). The relation between work-family balance and quality of life. Journal of vocational behavior, 63(3), 510531.

HUANG, Y. H., HAMMER, L. B., NEAL, M. B., \& PERRIN, N. A. (2004). The relationship between workto-family conflict and family-to-work conflict: A longitudinal study. Journal of Family and Economic Issues, 25(1), 79-100.

ILIES, R., SCHWIND, K. M., WAGNER, D. T., JOHNSON, M. D., DERUE, D. S., \& ILGEN, D. R. (2007). When can employees have a family life? The effects of daily workload and affect on work-family conflict and social behaviors at home. Journal of Applied Psychology, 92(5), 1368

IMOISILI, O.A.(1985). Task Complexity, Budget Style of Evaluating Performance and Managerial Stress: an Empirical Investigation. Ph.D. dissertation. University of Pittsburgh
KARATEPE, O. M., \& KILIC, H. (2007). Relationships of supervisor support and conflicts in the work-family interface with the selected job outcomes of frontline employees. Tourism management, 28(1), 238-252.

KESER, A. (2006). Çağrı merkezi çalışanlarında iş yükü düzeyi ile iş doyumu ilişkisinin araştırılması. Kocaeli Üniversitesi Sosyal Bilimler Dergisi, (11), 100-119.

KIRMEYER, S. L., \& DOUGHERTY, T. W. (1988). Work load, tension, and coping: Moderating effects of supervisor support. Personnel Psychology, 41(1), 125139.

KRAIMER, M. L., \& WAYNE, S. J. (2004). An examination of perceived organizational support as a multidimensional construct in the context of an expatriate assignment. Journal of Management, 30(2), 209-237.

LEITER, M. P., \& MASLACH, C. (2005). Banishing burnout: Six strategies for improving your relationship with work. John Wiley \& Sons.

LU, L., KAO, S. F., CHANG, T. T., WU, H. P., \& COOPER, C. L. (2008). Work/family demands, work flexibility, work/family conflict, and their consequences at work: A national probability sample in Taiwan. International Journal of Stress Management, 15(1), 1.

MAJOR, D. A., FLETCHER, T. D., DAVIS, D. D., \& GERMANO, L. M. (2008). The influence of work-family culture and workplace relationships on work interference with family: A multilevel model. Journal of Organizational Behavior: The International Journal of Industrial, Occupational and Organizational Psychology and Behavior, 29(7), 881-897.

MESMER-MAGNUS, J., MURASE, T., DECHURCH, L. A., \& JIMÉNEZ, M. (2010). Coworker informal work accommodations to family: Scale development and validation. Educational and psychological measurement, 70(3), 511-531.

NETEMEYER, R. G., BOLES, J. S., \& MCMURRIAN, R. (1996). Development and validation of work-family conflict and family-work conflict scales. Journal of applied psychology, 81(4), 400.

NG, T. W., \& SORENSEN, K. L. (2008). Toward a further understanding of the relationships between perceptions of support and work attitudes: A meta-analysis. Group \& Organization Management, 33(3), 243-268.

O'DRISCOLL, M. P., POELMANS, S., SPECTOR, P. E., KALLIATH, T., ALLEN, T. D., COOPER, C. L., \& SANCHEZ, J. I. (2003). Family-responsive interventions, perceived organizational and supervisor support, work-family conflict, and psychological strain. International Journal of Stress Management, 10(4), 326. 
ÖZKAN, Ç., ESİTTİ, B., \& KÖLEOĞLU, N. (2015). Work-Family Conflict In Hospitality Industry Employees: An Application In Izmir. Journal of Life Economics, 2(2), 75-88.

PARASURAMAN, S. \& SIMMERS, C. A. (2001). Type of Employment, Work-Family Conflict and Well-Being: A Comparative Study". Journal of Organizational Behavior, 22.

SHIROM, A., TOKER, S., ALKALY, Y., JACOBSON, O., \& BALICER, R. (2011). Work-based predictors of mortality: A 20-year follow-up of healthy employees. Health Psychology, 30(3), 268.

ŞİRİN, S., \& YUCEL, İ. Meslektaş Desteği İle Ağır İş Yükü İlişkisinde İş-Aile Çatışmasının Aracılık Rolü. Atatürk Üniversitesi İktisadi ve İdari Bilimler Dergisi, 34(1), 241-256.

THOMPSON, C. A., \& PROTTAS, D. J. (2006). Relationships among organizational family support, job autonomy, perceived control, and employee well-being. Journal of occupational health psychology, 11(1), 100.

TOPGÜL, S. (2016). İş ve aile yaşamı dengesi (zliği) nin kadın çalışanlar üzerindeki etkileri. Yönetim ve Ekonomi: Celal Bayar Üniversitesi İktisadi ve İdari Bilimler Fakültesi Dergisi, 23(1), 217-231.

TURGUT, T. (2011). Çalişmaya tutkunluk: iş yükü, esnek çalişma saatleri, yönetici desteği ve iş-aile çatişmasi ile ilişkileri. Atatürk Üniversitesi İktisadi ve İdari Bilimler Dergisi, 25(3-4), 155-179.

TURUNÇ, Ö., \& ÇELIK, M. (2010). Algılanan örgütsel desteğin çalışanların iş-aile, aile-iş çatışması, örgütsel özdeşleşme ve işten ayrılma niyetine etkisi: Savunma sektöründe bir araştırma. Atatürk Üniversitesi Sosyal Bilimler Enstitüsü Dergisi, 14(1), 209-232.

VOYDANOFF, P. (1988), “Work Role Characteristics, Family Structure Demands and Work-Family Confli$\mathrm{ct}^{\prime \prime}$, Journal of Marriage and Family, Vol. 50, No.3, 749761

WALLACE, J. E. (1999). “Work-to-Nonwork Conflict Among Married Male and Female Lawyers", Journal of Organizational Behavior, 20, ss.797- 816.

WANG, M., LIU, S., ZHAN, Y., \& SHI, J. (2010). Daily work-family conflict and alcohol use: Testing the cross-level moderation effects of peer drinking norms and social support. Journal of applied psychology, 95(2), 377.
YILDIRIM, D., \& AYCAN, Z. (2008). Nurses' work demands and work-family conflict: A questionnaire survey. International journal of nursing studies, 45(9), 1366-1378

YOON, J. \& LIM, J. C. (1999). Organizational support in the workplace: The case of Korean hospital employees. Human Relations, 52(7), 923- 945. 